\title{
Belgeo
}

Revue belge de géographie

3-4 | 2011

Human mobility and housing market during a period of global recession - Miscellaneous

\section{The state of the Hungarian residential market in the time of the global economic crisis}

Etat du marché résidentiel hongrois en période de crise économique mondiale

Mihály Tömöri and István Süli-Zakar

\section{(2) OpenEdition}

Journals

Electronic version

URL: http://journals.openedition.org/belgeo/6289

DOI: 10.4000/belgeo.6289

ISSN: 2294-9135

Publisher:

National Committee of Geography of Belgium, Société Royale Belge de Géographie

\section{Printed version}

Date of publication: 31 December 2011

Number of pages: 167-186

ISSN: 1377-2368

Electronic reference

Mihály Tömöri and István Süli-Zakar, «The state of the Hungarian residential market in the time of the global economic crisis », Belgeo [Online], 3-4 | 2011, Online since 15 December 2012, connection on 03 May 2019. URL : http://journals.openedition.org/belgeo/6289; DOI : 10.4000/belgeo.6289

This text was automatically generated on 3 May 2019.

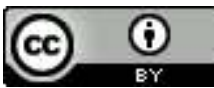

Belgeo est mis à disposition selon les termes de la licence Creative Commons Attribution 4.0 International. 


\section{The state of the Hungarian residential market in the time of the global economic crisis}

Etat du marché résidentiel hongrois en période de crise économique mondiale

Mihály Tömöri and István Süli-Zakar

\section{Introduction}

1 The housing situation in Central- and Eastern-Europe's former socialist countries has fundamentally changed since the years of political and economic transition. Socialist ideology regarded housing as a social service. According to this ideology reasonable housing conditions should have been provided for all households, regardless of their social or economic status. This ideological aim was to be achieved through the state housing policy, which meant that housing and building were totally controlled by the state. This strategy, however, did not solve the problem of housing, since it has remained a serious sociopolitical problem in Hungary up to the present time (Sailer-Fliege, 1996).

2 Housing in Hungary has undergone significant changes since the years of political and economic transition. During the socialist decades the housing sector was controlled by the state, market forces were marginal or non-existent. Thus, one of the biggest changes in housing was the establishment of a western-type residential market after the regime change.

The study starts by a short review of the literature on housing theories, then it briefly outlines the most important milestones in the development of the Hungarian residential market. This section is followed by the introduction of the most problematic issues and areas of the Hungarian residential market, and finally an analysis on the effects and consequences of the present economic crisis. 


\section{Theoretical approaches to housing}

4 The Hungarian and international literature on housing has grown rapidly in the past few decades. Despite the growing interest in housing related questions, researchers have primarily focused their attention to empirical and policy issues instead of theories and models (Kemeny, 1992 ; Marston, 2002). As a result, relatively few attempts have been made to elaborate a consistent theory of housing and no consensus has emerged around any model of analysis (Clapham, 1995).

5 Clapham (2002) distinguishes between four frequently used approaches to the study of housing. The state policy approach concentrates on describing and analysing government policy towards housing. The approach of neo-classical economics puts the emphasis on the relationships between different actors which are viewed through the framework of the market. The geographical approach aims to understand the factors, which influence the spatial distribution of housing. The sociological view applies the general sociological thought to the field of housing. Clapham (2002) argues that all these theories of housing are rather limited especially in the context of postmodern society. Consequently, he suggests the adoption of a new perspective based on social constructionism.

Kemeny and Lowe (1998) distinguish between three dominant perspectives on comparative housing research. According to them at one extreme are highly empirical approaches, while at the other extreme universalistic and highly generalising studies can be found. According to the authors there also exists an in-between category, which can be called "theories of the middle range". Empirical studies tend to lack a theory of housing and view each country as unique. On the other hand, generalising approaches emphasize similarities between countries and assume that all modern societies are developing in a particular direction, therefore this view is often termed as "convergence" perspective. Last but not least, the "theories of the middle range" adopt a more qualitative, culturally sensitive and historically grounded approach that are often called "divergence" perspectives.

7 During the past few decades numerous studies have focused on East European housing and various approaches have been taken to construct an East European model of housing. Hegedus and Tosics (1992) argue that due to cultural similarities similar housing systems have evolved in all East European countries, therefore a consistent East European housing model can be constructed.

Other researchers criticise the generalizing approach and question the existence of an East European housing model. Clapham (1995) argues that the East European housing model cannot be consistent, because there have been substantial differences among these group of countries. Lowe (1994) also criticises the concept of an East European housing model, because it does not take into account the differences among states, in addition, he argues that the analysis disregards the role of state action.

9 Kemeny and Lowe (1998) argue that East European housing models predominantly follow the convergence "approach". They argue that these models often assume that East European countries share a common past (communist legacy), therefore, following the regime change all these countries are converging towards more or less undifferentiated private market economies and housing systems. However, the authors argue that the generalising model of "transition" cannot and should not be assumed. 
10 The present paper adopts the geographical approach to introduce the factors that have influenced the development of the Hungarian residential market after the regime change. As a result much emphasis is placed on the spatial aspects and differences of the Hungarian housing market. The study primarily follows an empirical approach based on the latest available statistics emphasizing the effects and consequences of the economic crisis on households, the government and the residential market.

\section{The most important factors influencing the development of the Hungarian residential market after the political and economic changes in 1990}

11 The Hungarian housing market has undergone significant changes since the change of the regime, in which five main factors have played a dominant role (Kovács Z. et al., 2005) :

- declining population

- ageing population

- economic recession and income polarization

- rapid privatisation and deregulation of the housing market

- the emergence of foreign capital

The population of Hungary reached its post World War II peak in 1980 with 10,7 million people, since then it has been continuously declining. At the end of 2011 the population of Hungary will be around 9.9 million, which means that in the past 30 years there has been a decrease by 800 thousand people (Figure 1). Future prospects of population growth are not promising either. Population projections predict that the population decline and aging will continue in the following decades and if trends do not change Hungary's population will be only 8 million by 2050 (Hablicsek-Tóth, 2002). 
Figure 1. Hungary's population size (1960-2011).

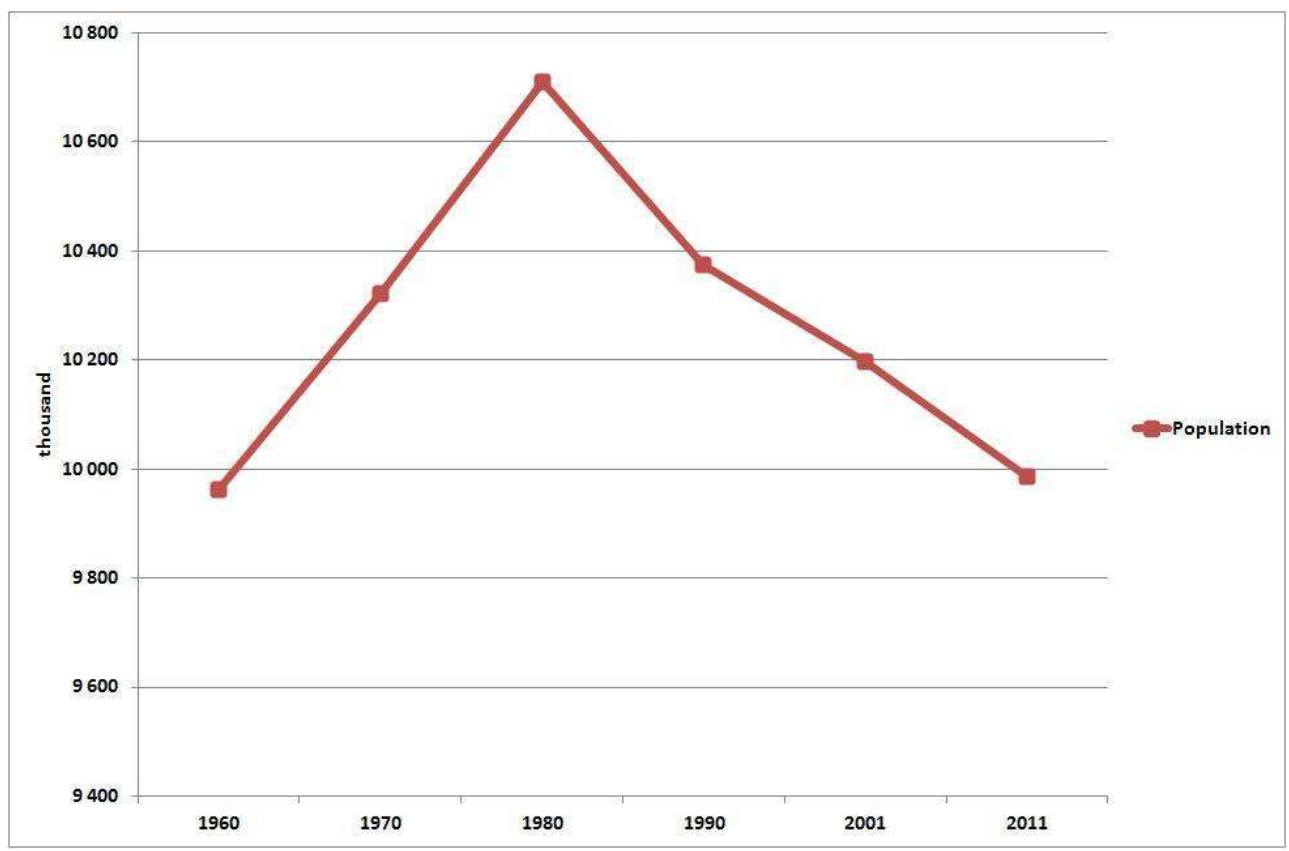

SOURCE : HCSO DATA, EDITED BY TÖMÖRI M.

Despite the continuous population decline the number of households has been increasing for the last few decades. This can be due to the gradual spread of modern lifestyle patterns and growing individualism, which has resulted in a decrease in the average size of households. These changes are particularly apparent in the case of one-person households (people living alone), whose number has more than doubled since 1960 (Table 1).

Table 1. Number and composition of households in Hungary (1960-2005).

\begin{tabular}{|l|l|l|l|l|}
\hline \multirow{2}{*}{ year } & \multirow{2}{*}{ number of households } & \multicolumn{2}{|l|}{ people living alone } & \multirow{2}{*}{ Average size of households (persons) } \\
\cline { 3 - 4 } & & number & share (\%) & \\
\hline 1960 & 3079101 & 446928 & 14.5 & 3.10 \\
\hline 1970 & 3377746 & 590207 & 17.5 & 2.95 \\
\hline 1980 & 3719349 & 730741 & 19.6 & 2.79 \\
\hline 1990 & 3889532 & 945973 & 24.3 & 2.60 \\
\hline 2001 & 3862702 & 1013889 & 26.2 & 2.57 \\
\hline 2005 & 4001976 & 1162727 & 29.1 & 2.47 \\
\hline
\end{tabular}

SOURCE : CENSUS DATA (1960-2001), MICRO-CENSUS DATA (2005), EDITED BY TÖMÖRI, M. 

of dwellings has been increasing. In 1980 the number of dwellings in Hungary was 3,542 million, which has increased to 4,348 million by 2011, which means that the stock of dwellings has grown by more than 800 thousand in the past 30 years (Figure 2).

Population decrease together with an increase in the stock of dwellings created an opportunity for households living together previously to move to separate dwellings. This has significantly reduced the proportion of overcrowded dwellings and improved living conditions. The previously mentioned trends are also reflected in the growing number and proportion of vacant dwellings. The share of vacant dwellings out of the total stock of dwellings was under $2 \%$ in 1960, while in 2001 this ratio was above $8 \%$ (Figure 2). This tendency can probably be due to the growing number of second homes and dwellings used for business purposes (e.g. offices).

Figure 2. Total number of dwellings (left axis) and percentage of vacant dwellings (right axis) in Hungary (1960-2011).

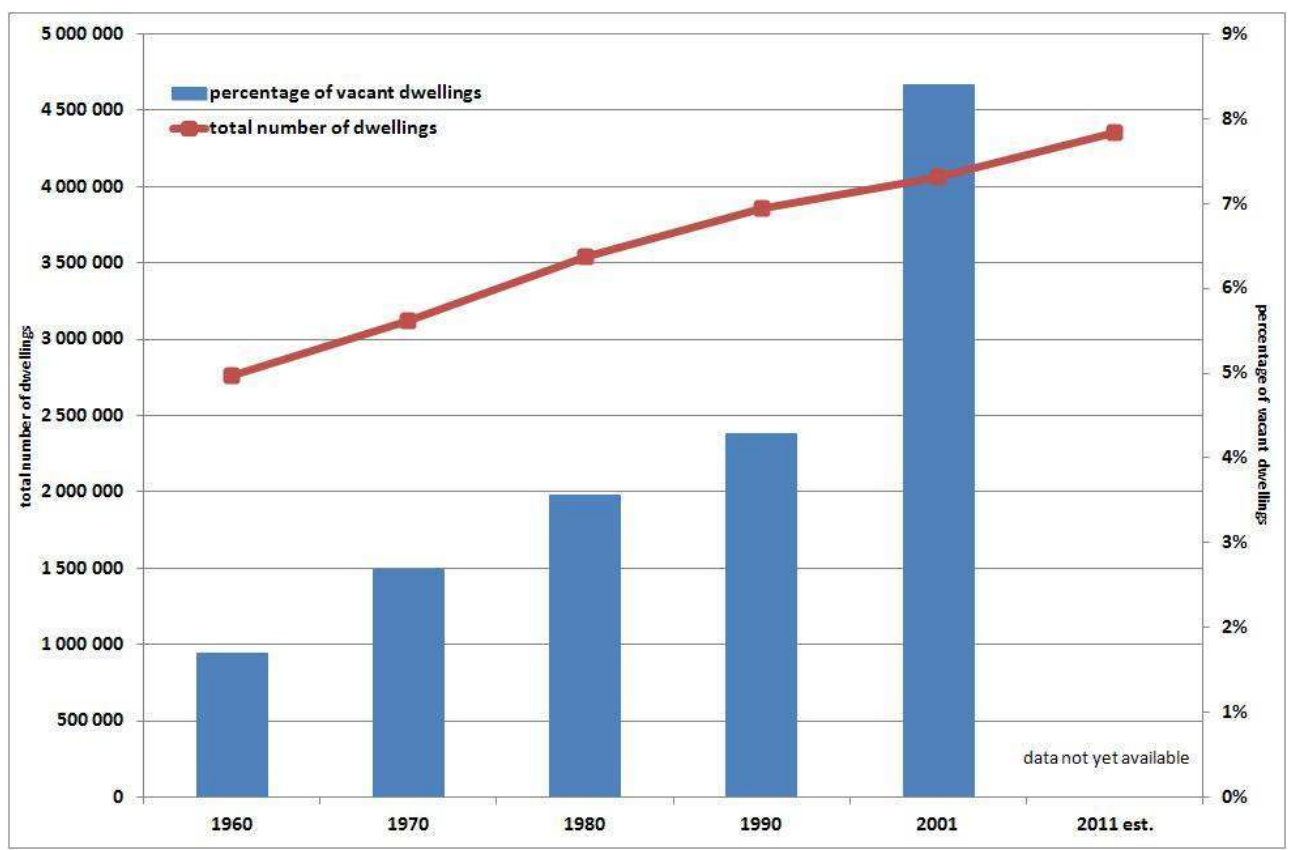

SOURCE : CENSUS DATA, EDITED BY TÖMÖRI M.

The dynamics of the housing market are strongly influenced by the general economic conditions (Farkas et al., 2004). From this perspective, the beginning of the 1990s was characterized by recession in Hungary. A modest increase in GDP started in 1994, however this growth was coupled with high inflation. Significant and long-lasting GDP growth started in 1997 and lasted until 2007 (Figure 3). Nevertheless, this growth was geographically uneven, and structural economic problems prevailed in certain regions of Hungary (e.g. in the Northern industrial areas). Despite the increasing income levels the housing market became slowly profitable, consequently the real upturn in housing only appeared after 2000. In addition, a strong income polarization has emerged since the economic and political transition, resulting in significant regional disparities between the core areas and the peripheries. 
Figure 3. Inflation and GDP growth rate in Hungary (1990 - Q1-Q3 2011).

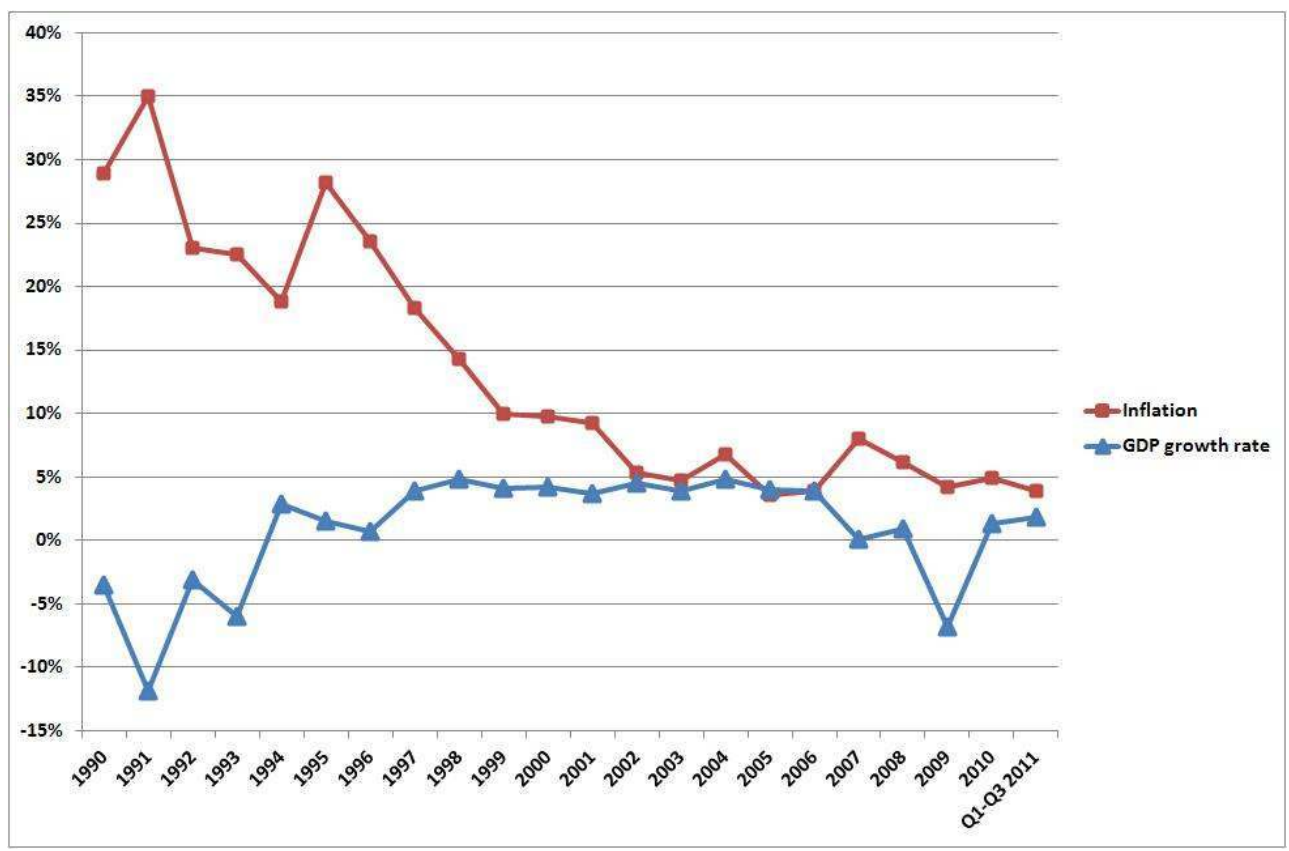

SOURCE : HCSO DATA, EDITED BY TÖMÖRI M.

Yet another important factor in the development of the housing market was rapid privatisation (Clapham, 1995 ; Clapham etal., 1996). As compared to Western-European countries, the proportion of privately owned homes was much higher even before the change of the regime, because the state supported private building through favourable state loans and grants. Consequently, the share of privately owned homes had reached almost 80 \% by 1990 (Sailer-Fliege, 1996 ; Kovács Z. et al., 2005).

Following the regime change (1989) political debate on housing and reforms focused almost exclusively on privatisation of the housing system (Clapham, 1995 ; Struyk, 1996). After the change of the regime the former state owned homes were transferred to local governments, making their rapid privatisation possible (Kovács, 1998). Within the framework of privatisation tenants could buy their homes under particularly favourable conditions - usually far below the real market prices (Sailer-Fliege, 1996). As a result, the number and proportion of flats owned by the state or local governments is minimal today (below $5 \%$ ) and the Hungarian residential market is dominated by private ownership (app. $95 \%$ ) (Kovács Z. et al., 2005 ; ECOSTAT, 2009). The deregulation of the housing market did not confine itself to privatisation alone, since it was also an important change that decisions on housing issues were delegated from the state level to local level. These changes decentralized housing-related decisions, such as where and what could be built (Kovács Z. et al., 2005).

Last but not least, as part of deregulation, with the opening of borders foreign capital gradually appeared in the Hungarian housing market. The emergence of foreign investors has been especially noticeable in two areas; on the one hand as capital investors (especially in Budapest), on the other hand as private buyers of flats and second homes (especially in Budapest and tourist regions, such as Lake Balaton and its surroundings). These factors together have resulted in the increasing spatial differentiation of the Hungarian housing market after 1990 (Kovács, 1998 ; Kovács Z. et al., 2005). 


\section{The most problematic areas of the current Hungarian residential market}

In the light of the above processes, currently there are four characteristic areas which present acute socioeconomic problems for Hungarian housing- and socio-politics :

- Rural areas, peripheries

- High-rise housing estates

- Suburbs

- Gated communities

\section{Rural areas, peripheries}

Hungary's spatial structure has fundamentally altered after the regime change. The industrial spatial structure characteristic of the socialist era has been replaced by a post industrial, tertiary spatial structure (Figure4). The beneficiaries of the changes have become those regions and cities which could successfully integrate into the global economic system. In the case of Hungary, Budapest and the Northwestern areas of Transdanubia have become the new core areas of post-socialist economic and social structure. The biggest losers have been those heavy industrial regions that were developed and strongly supported during the socialist era as well as the peripheries along the Northeastern borders of Hungary (Figure 4).

Figure 4. Current spatial structure of Hungary.

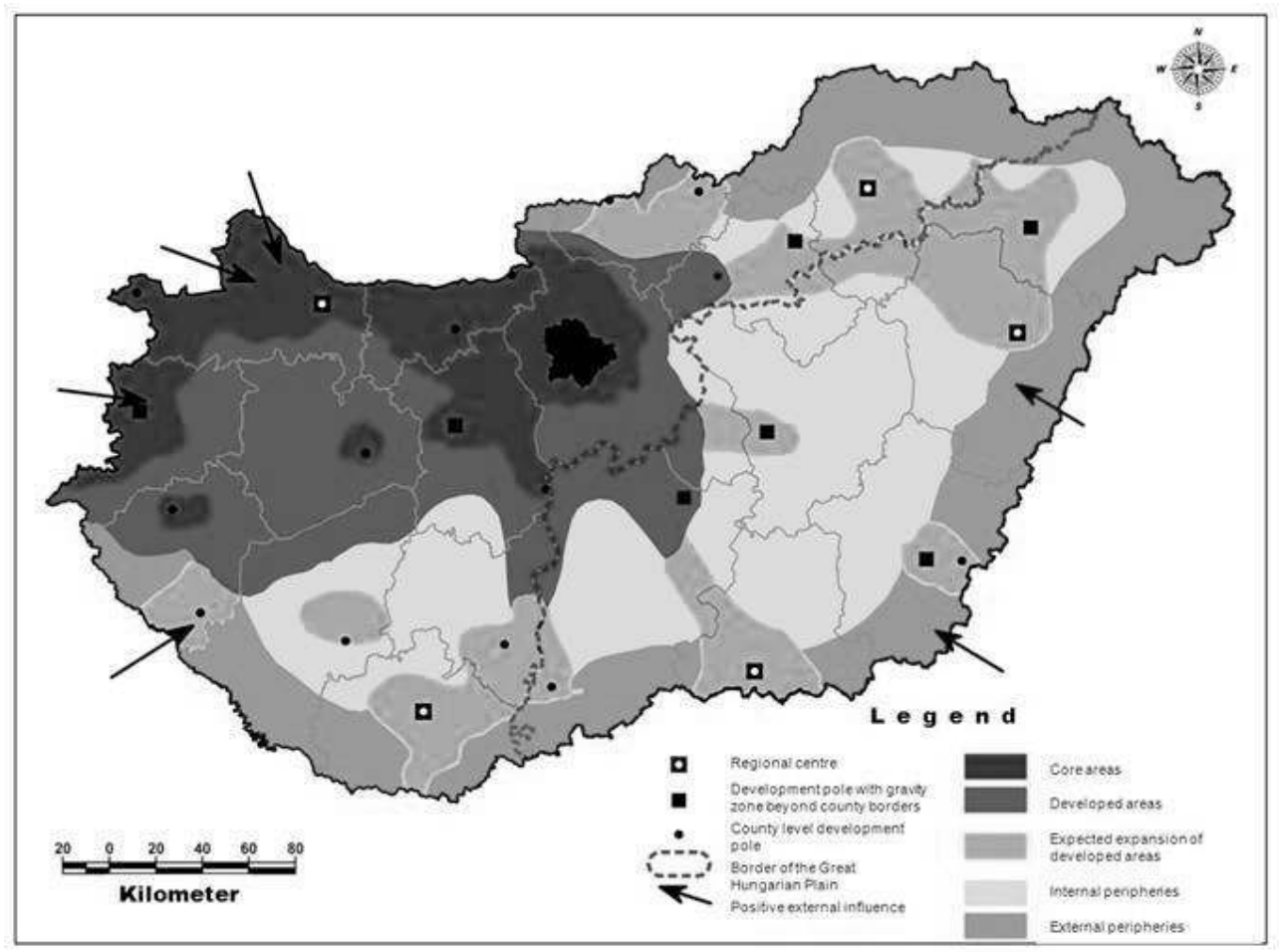

SOURCE : EDITED BY SÜLI-ZAKAR I. 
These peripheries suffer from multiple disadvantages, such as an ageing and declining population. Due to the high levels of unemployment they are characterized by continuous out-migration. This out-migration, however, is selective in nature, since primarily younger, more educated and wealthier social layers leave these areas. Consequently, peripheries are characterized by ageing and declining population. At the same time, uneducated, lower social class people move into these areas. This process can be termed as "suburbanization of the poor" when lower social class people move from cities to rural peripheries in the hope of cheaper living conditions (see section on suburbs). Obviously, the incoming poorer people are unable to maintain or renovate their homes adequately, as a result, the conditions of these dwellings are continuously worsening, their prices are falling, making these homes virtually unsellable. Consequently, there appears a growing gap in the prices of homes between the core areas and the peripheries (Figure 5).

Figure 5. Dwelling prices in Hungary according to settlement types (first half-year 2011).

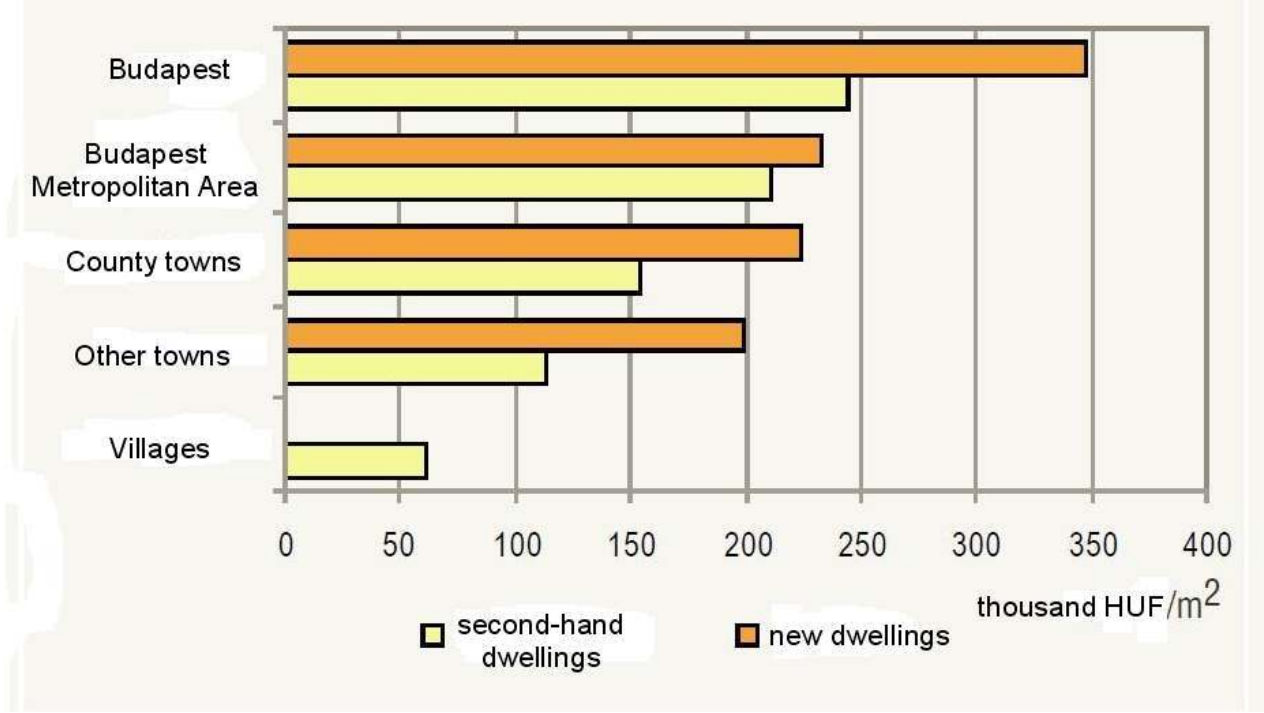

SOURCE : HCSO DATA.

This means that people living in peripheries are unable to move or to work in the core areas, because their homes are unsellable or so worthless that they cannot buy another home in developed and prosperous regions. Thus there is a paradoxical situation, since people living in peripheries are unable to change their situation even if they are willing to do so, because their homes virtually tie them to the peripheries.

The rising number and proportion of the roma population generates increasing social and ethnic conflicts especially in the Northeastern areas of Hungary. The natural birth rate among the roma population is much higher than among the Hungarians, moreover the proportion of lower social class people within the romas is also far above the country average. As a result, it is not surprising that their number and percentage is continuously increasing in the most underdeveloped rural peripheries of Northeastern-Hungary. The level of comfort of their homes are extremely low, the percentage of dwellings made out of adobe is particularly high. In addition, the districts occupied by romas are usually spatially segregated, and these homes are often situated in areas threatened by floods. Unfortunately, during the recent floods of May and June 2010, more than 3000 homes have collapsed, primarily in the Northeastern areas of Hungary. The current aim of the 
Hungarian government is to implement complex reconstruction programs in the areas damaged by floods, which would result in basic structural changes in the spatial pattern of settlements. The reconstruction of areas damaged by floods would create an opportunity to improve the domestic construction industry suffering from the economic crisis and to create new jobs with the involvement of local small- and medium-sized enterprises.

\section{High-rise housing estates}

Another important problem of the Hungarian housing market is represented by high-rise housing estates built during the socialist era. In Central- and East European countries housing estates became widespread after World War II and dominated the housing market for almost forty years. The idea of building new housing in concentrated forms served as a tool for the large-scale public housing construction program that was intended to address the housing shortage (Tosics, 2004). The frequent occurrence of this building type in the former Eastern bloc was not only a solution to housing shortage, but fulfilled an important ideological role as well. High-rise housing estates also contributed to the process of urbanisation and the development of infrastructure, giving a chance for millions of people to enjoy better living conditions than previously (Egedy, 2000). The goal and ideology of the socialist housing policy was the equalisation of housing conditions for all households (Sailer-Fliege, 1999).

Due to the significant heavy industrial investments and the related industrial jobs, huge numbers of people migrated from rural areas to Budapest and to the new heavy industrial centres during the socialist decades. As a result, the demand for new housing increased rapidly in the biggest cities (Budapest, Debrecen, Miskolc, Szeged, Pécs, Györ) and industrial regions, thus large numbers of new homes had to be built in a relatively short time for the incoming population. In the framework of the state housing policy, masses of blocks of flats were built especially during the 1970s, although the construction of highrise housing estates lasted in most socialist countries up till the collapse of socialism (Tosics, 2004).

These blocks of flats were constructed out of prefabricated panel blocks made in "housebuilding factories" that flooded most East European cities with low-quality housing (Szelényi, 1996). These buildings were constructed with obsolete technology, their level of modern convenience, technical and mechanical equipment were obsolete even at the time of their construction. In addition, the energy efficiency of most of these buildings is especially low, because they do not have external wall insulation. Consequently, the heating energy demand of these blocks of flats is extremely high in comparison with modern buildings. These days, this causes an increasingly serious problem, since energy prices have raised significantly worldwide in the past few decades.

High-rise housing estates provide quite unfavourable living conditions, since they are often located in undesirable neighbourhoods and poorly served by public transportation and other services (Szelényi, 1996). Numerous studies have proven that the percentage of people dissatisfied with their living conditions and intending to move away is the highest among those living in blocks of flats. As a result, a selective migration started from these buildings as early as in the 1980s, which marked the beginning of a strengthening segregation process. The selective nature of this migration meant that younger, higher social status layers gradually moved away from these buildings, while the proportion of 
older, poorer, lower social class people started to increase. Naturally, this process caused a fall in the price and prestige of these flats, thus the process became self-generating and the incoming of lower social class people continued. As a result of selective segregation processes, these areas were populated by low to very low social status groups in all socialist states at the end of the socialist era (Sailer-Fliege, 1999).

Nowadays, high-levels of old-age pensioners, unemployed and lower social class people characterize the population of the majority of these high-rise housing estates. In most large cities at least over one third of all households live in high-rise housing estates (Sailer-Fliege, 1999). This means an especially serious problem, since these flats should be renovated, their energy efficiency should be increased, however, their dwellers are generally in a bad economic situation, so they are unable to finance these renovations by themselves.

31 The previous government (led by Mr. Ferenc Gyurcsány between 2006-2009) launched a reconstruction program targeting panel buildings, whereby one third of the total renovation costs were covered by the central budget, one third by local governments and one third by homeowners, but this program only scored modest success. The major reason for the limited results was due to restricted financial sources. The new government elected in April 2010 aims to continue and accelerate the reconstruction program. This program aims to speed up renovations, achieve higher energy savings (at least $60 \%$ ) and widely apply renewable energy resources.

\section{Suburbs}

One of the most spectacular spatial processes in Hungary was suburbanization during the 1990s. The usually young, wealthy households migrating from large cities to rural areas make the outskirts of cities and villages dynamic. Perhaps the most characteristic example of suburbanization in Hungary is the Budapest metropolitan area, although to a lesser extent suburbanization also emerges on the outskirts of the biggest Hungarian cities such as Szeged, Miskolc, Debrecen, Eger, Pécs (Dövényi Z., 2007 ; Kovács Z. et al., 2005). An important difference, however, is that suburbanization is much more developed in the surroundings of Transdanubian cities than in cities in the Eastern parts of the country (Figure 6). 


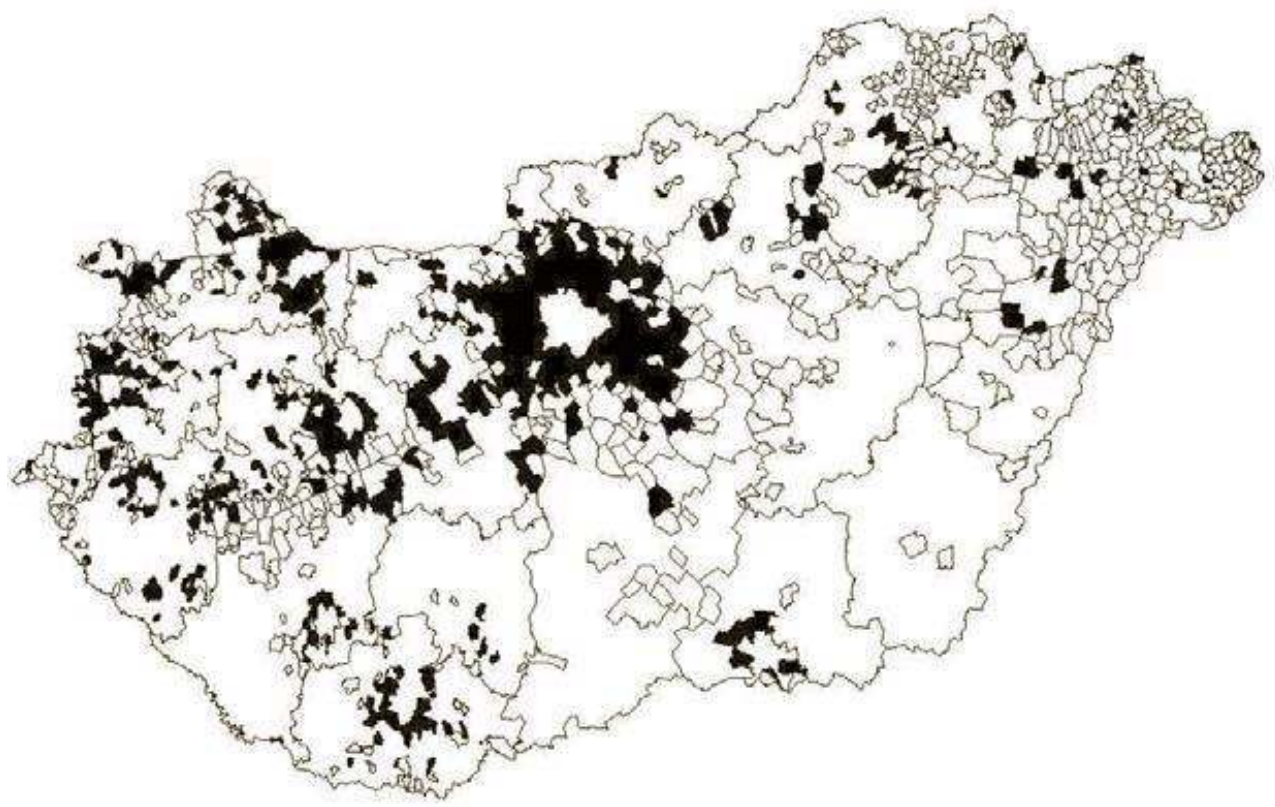

Source : Kovács Z. et al., 2005, 470 p.

As suburbanization in Hungary shows the greatest extent within the Budapest metropolitan area, the characteristic features can best be demonstrated through this example. The migration balance of Budapest and Pest county was positive for the capital until the mid-1980s, in 1987, however, the balance changed - Budapest realized negative migration, while its environment, Pest county, realized positive migration. The alteration of the balance and direction of migration became more spectacular after the change of the regime (Figure 7). During the 1990s previously unknown or little-known processes and phenomena of migration and mobility emerged in Budapest and its surroundings (Dövényi Z., 2007). Between 1990 and 2001, the population of Budapest declined by 238 thousand, of which migration losses comprised app. 50 \% (Kovács Z. et al., 2005). The fact that within the Budapest metropolitan area suburbanization is the most important spatial process indicates the scale and significance of suburbanization. The reason for this kind of suburbanization process lies in the fact that this phenomenon around Budapest can be grouped into the "residential suburbanization" category, that is, the suburbanization of economic and tertiary functions has not been significant yet. Suburbanization, however, was not limited to the Budapest metropolitan area after 1990, it appeared in all of the bigger metropolitan areas, moreover, it emerged around smaller towns, as well. As a result, it can be stated firmly that suburbanization has become a characteristic feature of inland migration and the Hungarian residential market (Dövényi Z., 2007). 


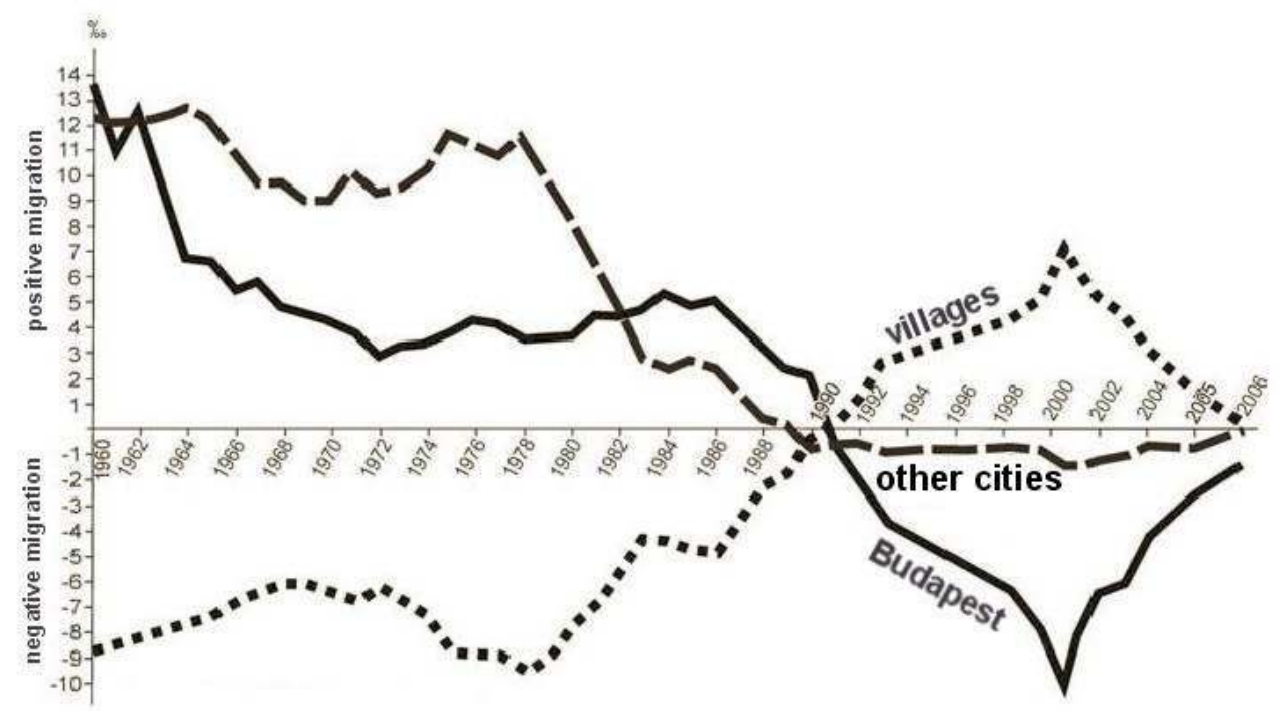

SOURCE : DövÉNYI Z., 2007, 355 P. (MOdIfied BY THE AUTHORS). original notion of suburbanization, instead, it can be regarded as an escape from cities, nevertheless, the direction of migration is the same in both cases. This phenomenon is characteristic of those impoverished layers of society that "escape" from cities to the outskirts of big cities or rural areas in the hope of a cheaper but also lower-level lifestyle. Lower social class migrants leaving Budapest or bigger cities target either the niche areas of traditional suburbanization or rural areas. The "suburbanization of the poor" practically means the exportation of social problems from cities to rural areas (Dövényi, 2007).

\section{Gated communities}

Gated communities represent a special urban development, architecture and social phenomenon of our globalizing world. Today, gated communities are getting betterknown and more widespread around the world (Blandy et al., 2003). Modern gated 
communities appeared in Central- and Eastern-Europe after the fall of communist regimes. In the course of introducing the market economy, income disparities in these countries have risen enormously, which manifested itself in the strengthening segregation of the urban population. Gated communities represent a characteristic form of this segregation. In developed countries gated communities mean a residential area created by real estate developers that are often physically separated (e.g. gates, fences) and equipped with controlled entrance and/or video control system. It is important to emphasize that gated communities are not only physically separated, but the social norms of residents are also different from other layers of society. In Hungary the first gated communities were established at the end of the 1980s and at the beginning of the 1990s. They appeared first in Buda, then they became widespread in all parts of Budapest and in the suburbs, as well. Today, gated communities are not only present in Budapest and its metropolitan area, but they can also be found all around the country. Most gated communities are to be found in Budapest and its agglomeration zone, but their number is significant in the case of regional centres and in some county towns as well. However, gated communities rarely appear in small- or medium-sized towns (Figure 8).

Figure 8. Spatial distribution of gated communities in Hungary, 2010.

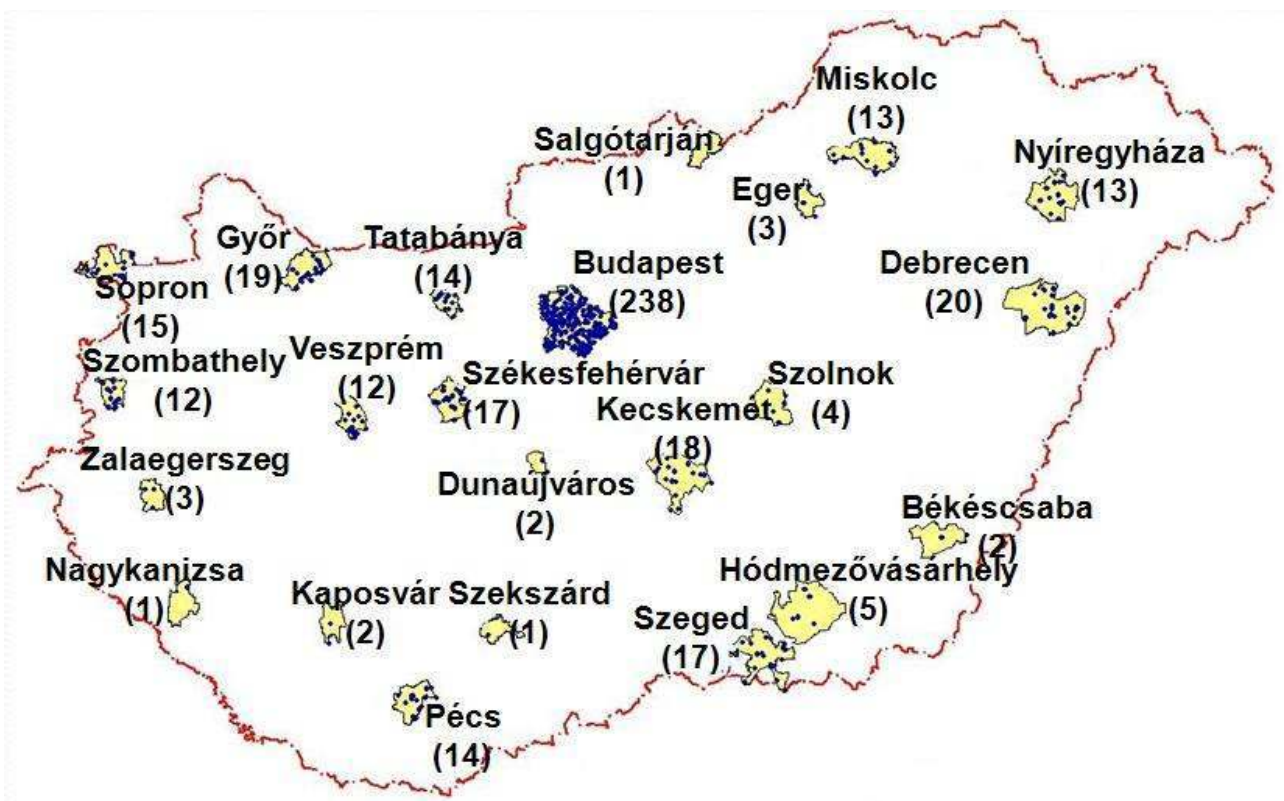

SOURCE : EDITED BY SÜLI-ZAKAR I.

Gated communities are usually established in those areas where both the social geographic (e.g. upper middle-class, high income levels, excellent transport infrastructure, etc.) and the physical geographic factors (e.g. pleasant green parks, fresh air, panoramic view, lakeside, etc.) are favourable at the same time.

Most gated communities in Hungary do not resemble their Western-European or American counterparts in terms of the strict scientific definition - they are not under guard, do not have controlled entrance, are not completely separated from their environment, do not have legal "independence" and offer relatively few extra facilities for their residents. Gated communities are populated by the upper middle-class in Hungary, as well, the primary motivation for moving into gated communities are the modern apartments and the pleasant environment. However, due to the relatively good 
public security, fear of crime and prevention of crime only play a marginal role in moving to gated communities in Hungary as opposed to gated enclaves in Latin-American countries (Cséfalvay, 2007 ; Hegedüs, 2008).

\section{The economic crisis and its consequences on the Hungarian residential market}

Mortgages denominated in foreign currencies appeared in Hungary in 2004, and became widely popular, because of low interest rates as compared to forint loans. This is wellillustrated by the fact that in 2005 interest rates on mortgages denominated in Swiss francs were around $4 \%$, while rates on forint loans were above $10 \%^{1}$. The huge gap between interest rates appeared, because the former system of interest rate subvention on forint housing loans was stopped in order to cut back on government spending. Former governments seemed to profit from the spread of foreign currency mortgages, since the residential market was dynamic even without state subventions, consumption increased, which contributed to economic growth. Moreover, the central budget deficit was not increased by interest rate subventions and the risk of exchange rate fluctuations were taken by those who took out foreign-currency mortgages (HVG, 2010). However, the risk of foreign-currency loans was obvious ; since all the borrowers had income in forints, not francs. If the forint lost value, loan payments could multiply. However, lower interest rates meant lower monthly payments, as a result a buyer who could not hope to get a loan in Hungarian forint could easily qualify for a Swiss franc loan. That is why a vast majority of mortgage loans were made in Swiss francs.

41 The number and the total stock of foreign currency mortgages increased rapidly until the outbreak of the credit crisis in 2008. At the beginning of 2011 roughly $30 \%$ of Hungary's all external debt was denominated in CHF, nearly $90 \%$ of which was held by households ${ }^{2}$. By the time the financial crisis began, two-thirds of mortgage loans in Hungary were denominated in Swiss francs ${ }^{3}$. According to the latest statistics, Hungarian household mortgages totalled 4.1 billion $^{4}$ forint ( 13.2 thousand million euros ${ }^{5}$ ) of which 63 percent were denominated in foreign currencies, according to central bank data ${ }^{6}$.

Due to the economic crisis and the restrictions imposed on credit conditions the dynamic growth of the credit market stopped in 2008, which was followed by a huge downturn in 2009. The total sum of mortgages stagnated, while the number of new mortgages, especially non-forint denominated loans has dropped significantly since 2008. New foreign-currency loans have virtually disappeared from the market by 2010 (Figure 9). 
Figure 9. Number of new mortgages by year (2002-2010).

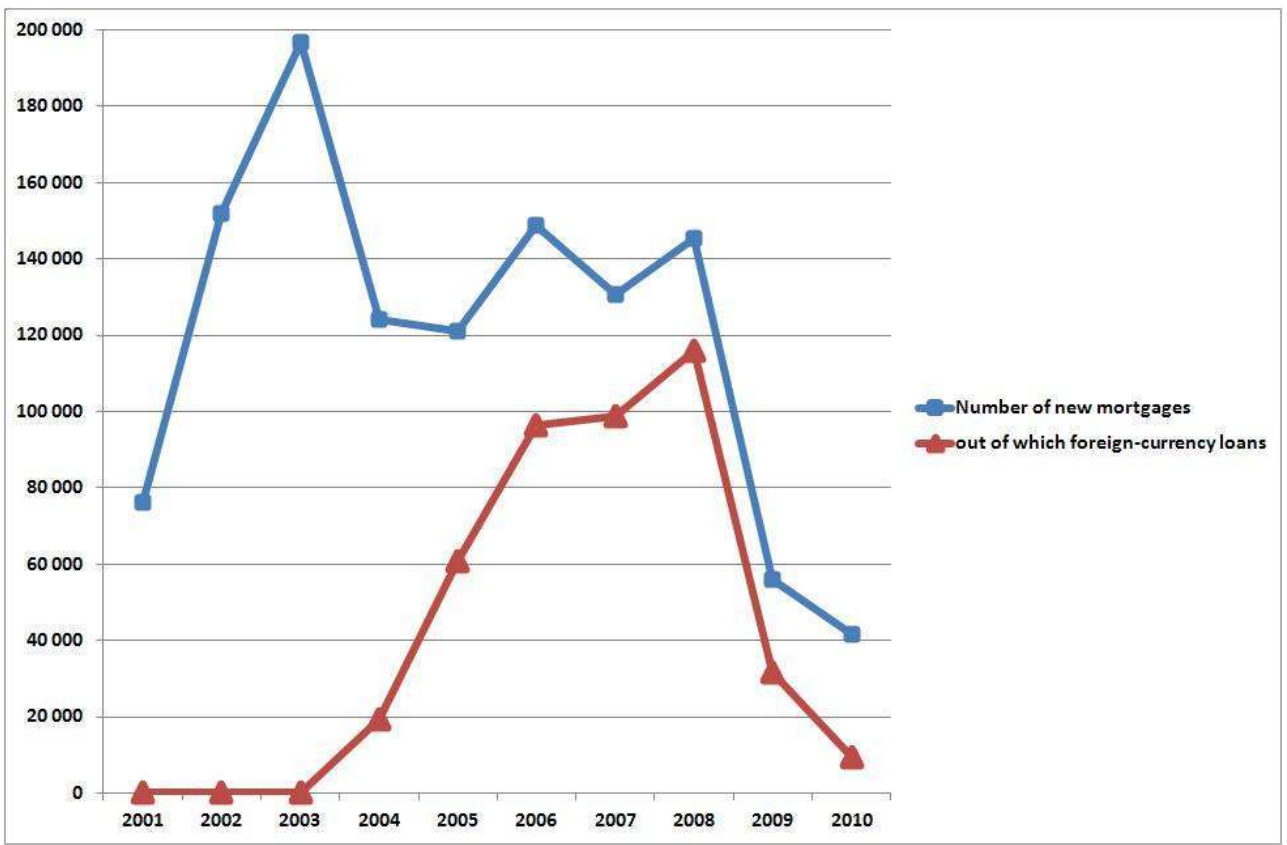

SOURCE : HCSO DATA, EDITED BY TÖMÖRI M.

43 The credit- and economic crisis quickly revealed the huge risks of foreign currency mortgages. Due to the global economic crisis and the structural problems of the Hungarian economy the Hungarian forint has significantly weakened against other currencies and especially against the Swiss franc. Moreover, in light of the current global turmoil, the CHF has become a safe haven ${ }^{7}$, making the Alpine currency even stronger against the forint (Figure 10). In October 2011 the Hungarian forint was around 250 to the Swiss franc, which has resulted in a significant increase in Swiss franc denominated mortgage payments, since most of the loans were taken out at exchanges rates from 140 to 180 forints to the franc ${ }^{8}$. 
Figure 10. CHF/HUF exchange rate (January 2004 - October 2011).

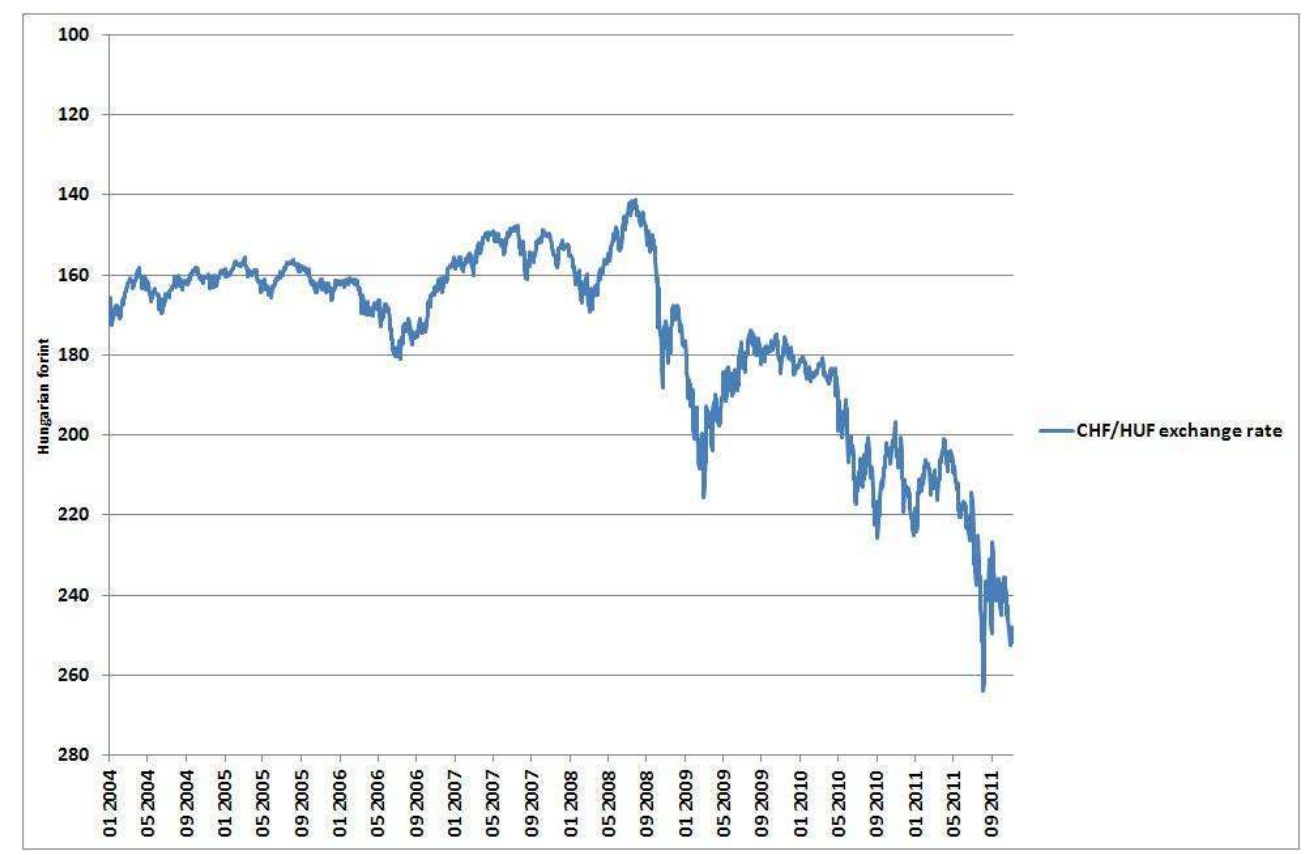

SOURCE : HUNGARIAN NATIONAL BANK DATA, EDITED BY TÖMÖRI M.

Things were only worsened by the fact that the financial crisis gradually transformed into an economic crisis, which resulted in loss of jobs, the rate of unemployment $(11.2 \%$ in 2010) has risen to a record height for the past ten years in Hungary. Consequently, unemployed debtors are facing an even more difficult situation. As a result, of the 1.1 million people that held mortgages denominated in foreign currencies, roughly 100,000 were in severe arrears by June 2011 and more are likely to follow 9 .

The Hungarian government and banks have been trying to tackle the problems caused by foreign-currency mortgages. The measures are aiming to protect those who can't pay back their mortgages and those who are suffering because of higher repayment obligations. Three major measures have been elaborated to help mortgage holders. According to the first option debtors can temporarily fix exchange rates on foreigncurrency household mortgages at 180 forint per Swiss franc or 250 forint per euro. The difference between the fixed-rate payments and the actual exchange rate will be booked in a separate forint account where the debt will accumulate or disappear if better exchange rates emerge. According to the agreement debtors will have to start repaying the difference as of January 2015 at a set interest rate ${ }^{10}$.

The second solution aims to help those who are unable to meet their mortgage payments. In order to achieve this goal, the government will set up a national asset manager that will take over the properties of non-paying debtors who will continue to rent their homes from the state. Families agreeing to move to a smaller home will be entitled to a state subsidy on the interest rate of their mortgages for five years. The asset manager will also launch a greenfield homebuilding program for those who lose their homes.

The third option for foreign-currency mortgage holders is to pay off the total sum of their loan at a fix exchange rate of 180 forint to the Swiss franc or 250 forint against the euro. The legislation allows debtors to clear their foreign-currency mortgages at well below the market exchange rate (though above the rate at which most mortgages were taken out). 
According to the Hungarian government the costs of foreign-exchange losses should be borne by the banks ${ }^{11}$. Those who would like to pay off their mortgage have to indicate their intention until December 30, 2011 and pay back the total sum until February 28, 2012.

The dynamism of economic growth and demographic conditions are clearly reflected in the dynamics of new dwelling construction. The peak of new dwelling construction in Hungary was during the 1970s and in the first half of the 1980s. During the 1970s the yearly average of newly constructed dwellings was around 90 thousand, out of which a significant percentage ( $40 \%)$ was due to state financed construction. Due to the gradual withdrawal of the state new dwelling construction decreased steeply after 1980 (Figure $11)$.

Figure 11. The volume of new dwelling construction in Hungary (1960-2011).

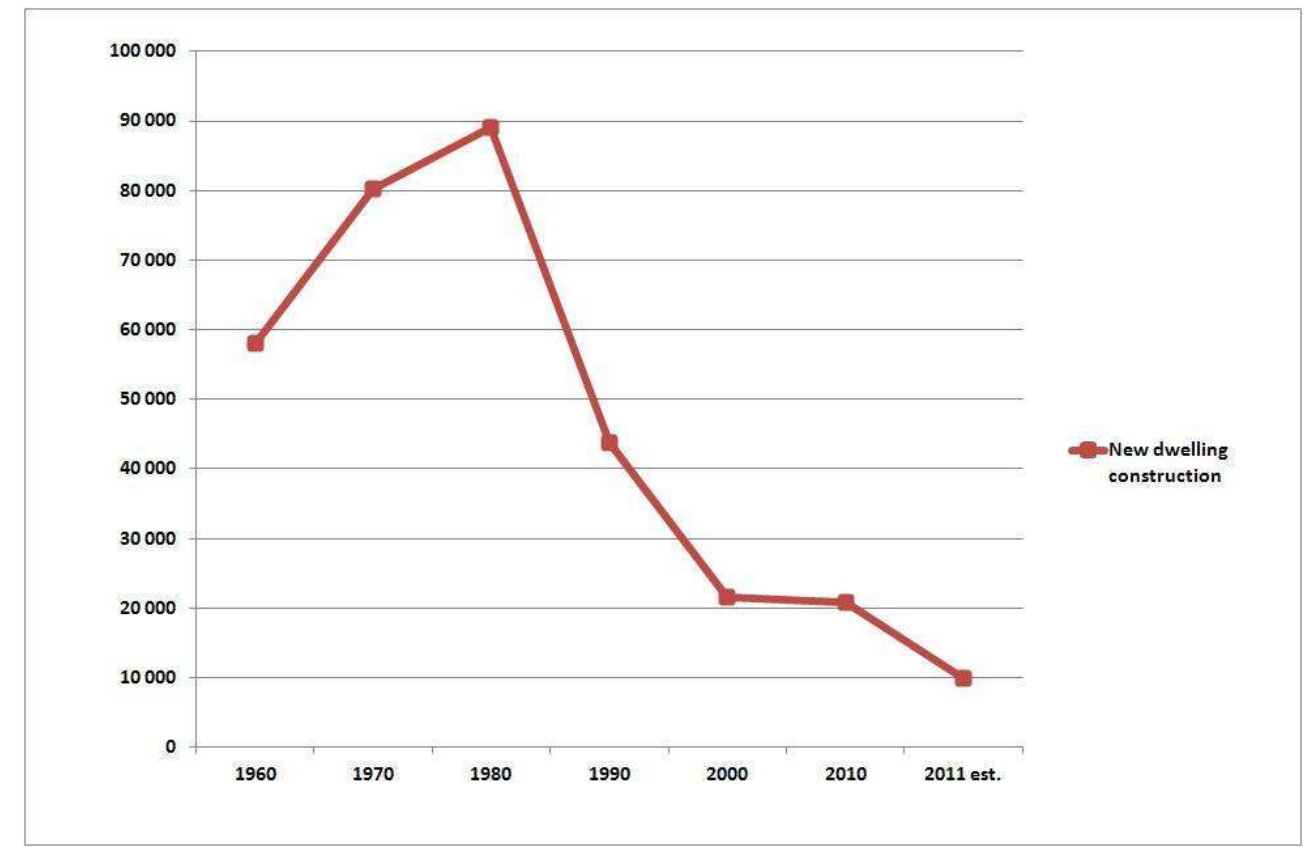

SOURCE : HCSO DATA, EDITED BY TÖMÖRI M.

At the beginning of the 1990s the fall of new dwelling construction continued and it reached its first bottom point between 1993 and 1994 (Figure 12). This was followed by a modest increase from 1995 until 1997, however in 1998 and 1999 an even worse downturn occurred, which was the second bottom point during the 1990s. Due to easing credit conditions and state-supported mortgage loans the Hungarian residential market witnessed a significant upturn during the first years of the $21^{\text {st }}$ century, which reached its peak in 2004. This was followed by a modest decrease and stagnation from 2005 until 2008. The outbreak of the economic crisis in 2008 has had a dramatic effect on the residential market, as new dwelling construction has been decreasing continuously since then. According to latest estimations new dwelling construction in 2011 can be around 10 thousand (Figure 12), which is the lowest figure in Hungary since the Second World War. 
Figure 12. The volume of new dwelling construction in Hungary (1990-2011).

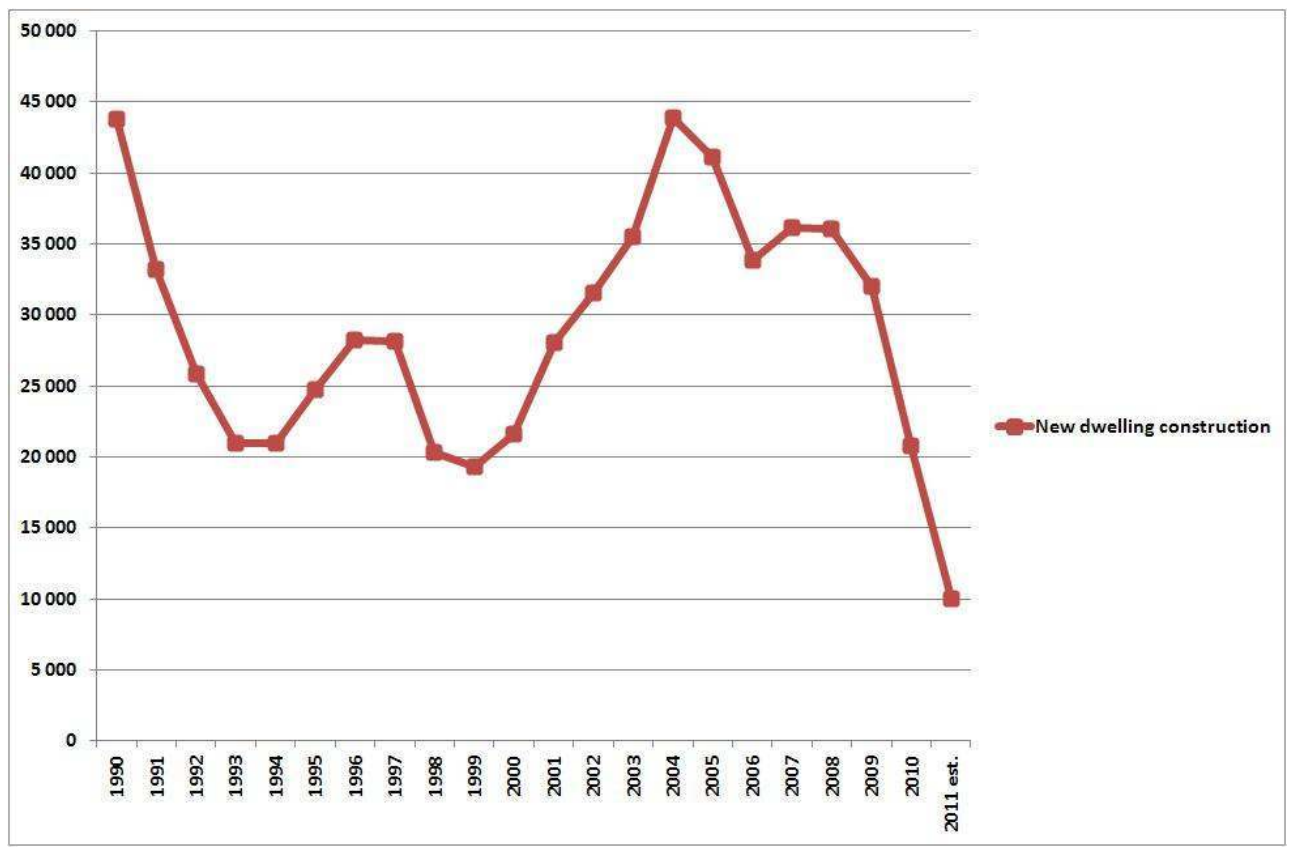

SOURCE : HCSO DATA, EDITED BY TÖMÖRI M.

The economic crisis has had a dramatic impact on the turnover of the housing market, as well. Due to the economic recession, the loss of jobs, the declining purchasing power and the restrictions imposed on credit conditions, the turnover of the Hungarian residential market has declined enormously. This fact is well-reflected in the turnover statistics of the Hungarian residential market showing that the number of dwelling sales has dropped by more than $50 \%$. In 2007 the number of dwelling sales was 191 thousand, while in 2010 this figure was only 90 thousand. The downturn strongly affected the market of new dwellings, since sales figures in 2010 (5 thousand) reached only one-third of the 2008 (14 thousand) data (Table 2).

Table 2. Number of dwelling sales in Hungary.

\begin{tabular}{|l|l|l|l|}
\hline year & second-hand dwellings & new dwellings & total \\
\hline 2007 & not available & not available & 191200 \\
\hline 2008 & 140000 & 14100 & 154100 \\
\hline 2009 & 82900 & 8300 & 91100 \\
\hline 2010 & 85500 & 4800 & 90300 \\
\hline first half-year 2011 & 35700 & 1700 & 37400 \\
\hline
\end{tabular}

SOURCE : HCSO DATA, EDITED BY TÖMÖRI M. 
51 agglomeration zone in the past few years, only $6 \%$ of the total turnover of new flats has been realized in villages, the majority of which are situated in the gravity zones of large cities (HCSO, 2010). In other words, the housing market has stopped functioning in rural areas. Due to the above mentioned tendencies the prices of homes have decreased significantly, old and low-comfort dwellings especially in rural or peripheral areas are virtually unsellable. Obviously, the changes in property prices have not affected equally the different geographical regions and the different types of dwellings. The most significant decline in (nominal) prices has affected the market of second-hand dwellings situated in villages in the peripheries. The nominal prices of new dwellings have stagnated in Budapest and in villages, while a significant decline has occurred in county towns and "other" towns (Figure 13). This means that inflation adjusted price-levels have dropped by 5 to $15 \%$ since 2007 .

Figure 13. Prices of flats per square metre in HUF by settlement types (2007-2010).

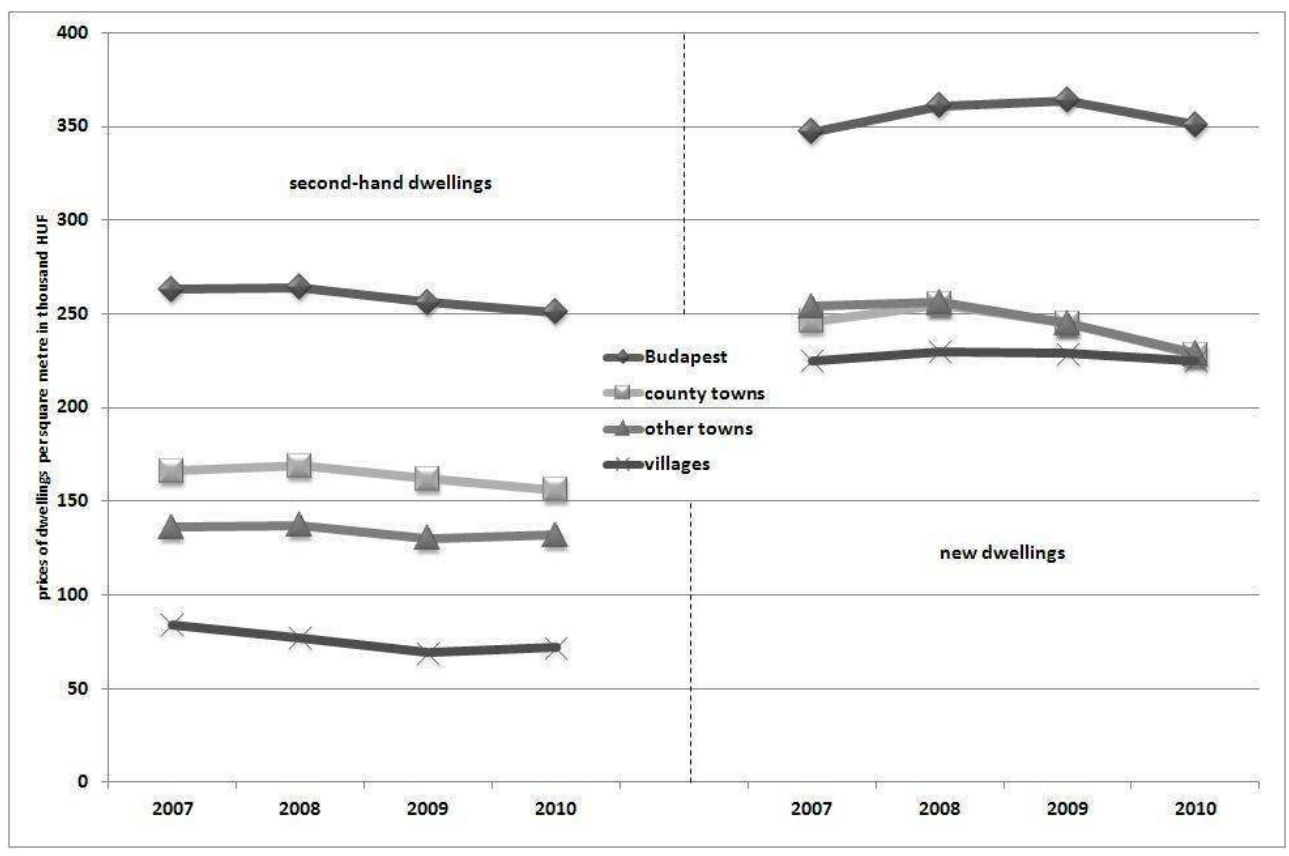

SOURCE : HCSO DATA, EDITED BY TÖMÖRI M.

\section{Conclusions}

This study has briefly outlined the most important milestones in the development of the Hungarian residential market, introduced the most problematic areas, and analyzed the effects and consequences of the present global economic crisis on housing conditions. Housing has considerably altered since the transition from socialism to free democracy and market economy. Generally, the winners of this transition have become Budapest and its metropolitan area and the Northwestern regions of Hungary. On the other hand, rural areas on the peripheries have turned out to be the biggest losers. The global financial and economic crisis has had devastating effects on the Hungarian economy and residential market. The crisis and its consequences have proved that the former model of economic growth based on easy foreign credit conditions is unsustainable, thus the world's and 
Hungary's economy has to shift towards a basically different and sustainable economic policy.

\section{BIBLIOGRAPHY}

BLANDY S., LISTER D., ATKINSON R., FLINT J. (2003), “Gated communities : A Systematic Review of the Research Evidence", CNR Paper 12, http ://www.neighbourhoodcentre.org.uk/research/ cnrpaperspdf/cnr12pap.pdf.

CLAPHAM D. (1995), "Privatisation and the East European Housing Model”, Urban Studies, 32, 4-5, pp. 679-694.

CLAPHAM D. (2002), "Housing Pathways : A Post Modern Analytical Framework”, Housing, Theory and Society,19, pp. 57-68.

CLAPHAM D., HEGEDÜS J., KINTREA K., TOSICS I. (eds.) (1996), Housing Privatization in Eastern Europe, London, Greenwood Press.

CSÉFALVAY Z. (2007), New Segregation with New Conflicts : Demystifying Gated Communities in Budapest, Paper presented at the $4^{\text {th }}$ International Conference of the research network Private urban governance \& gated communities held at the Université Paris 1 Panthéon-Sorbonne, 5-8 June 2007 (CD-ROM).

DÖVÉNYI Z. (2007), “A belföldi vándormozgalom strukturális és területi sajátosságai Magyarországon”, Demográfia, 50, 4, pp. 335-359.

EGEDY T. (2000), “The situation of high-rise housing estates in Hungary”, in KOVÁcS Z. (ed.), Hungary towards the $21^{\text {st }}$ century : the human geography of transition, Geographical Research Institute, Hungarian Academy of Sciences, Budapest, pp. 169-185.

FARKAS J., KOVÁCS Z., SZÉKELY G-né (2004), A magyar lakáspiac területi jellemzöi az ezredfordulón, Központi Statisztikai Hivatal MTA Földrajztudományi Kutatóintézet, Budapest, 169 p.

HABLICSEK L., TÓTH P. P. (2002), “The role of international migration in maintaining Hungary's population size between 2000-2050 “, Working papers on population, Family and welfare, No. 1, Central Statistical Office Demographic Research Institute, Budapest, 41. p.

HEGEDÜS G. (2008), “Az elzárkózó helyi társadalom - lakóparkok a vidéki magyar nagyvárosokban “, IV. Magyar Földrajzi Konferencia kötet, Rexpo, Debrecen, pp. 285-291.

HEGEDUS J. and TOSICS I. (1992), “Conclusion : past tendencies and recent problems of the East European housing model “, in TURNER B., HEGEDUS J., TOSICS I. (eds.), The Reform of Housing in Eastern Europe and the Soviet Union, London, Routledge.

KEMENY J. (1992), Housing and social theory, Routledge, London.

KEMENY J., LOWE S. (1998), "Schools of Comparative Housing Research : From Convergence to Divergence “, Housing Studies, 13, 2, pp. 161-176.

KOVÁCS Z. (1998), “Social and Economic Consequences of Changing Housing Policies in Hungary “, in HOLT-JENSEN A., MORRISON N. (eds.), Social Housing : International Comparison of Planning for the Weakest Social Groups, Geography in Bergen, Series B., pp. 98-107. 
KOVÁCS Z. et al., (2005), “A lakáspiaci dinamizmus néhány jellemzöje Magyarországon “, Statisztikai Szemle, 83, 5. pp. 461-479.

LOWE S. (1994) “Towards a social theory of housing in Eastern Europe “, in TANNINEN T. (ed.), Housing in Transition, Dresden, Bauhaus.

MARSTON G. (2002), “Critical Discourse Analysis and Policy-Orientated Housing Research “, Housing, Theory and Society,19, pp. 82-91.

NAGY E., TÍMÁR J. (2008), “A városmegújítás társadalmi következményei Európában “, IV. Magyar Földrajzi Konferencia kötet, Rexpo, Debrecen, pp. 307-313.

SAILER-FLIEGE U. (1996), “A debreceni lakáspiac és a társadalom térszerkezetének változásai “, Tanulmányok Debrecen Városföldrajzából II, Kossuth Lajos Tudományegyetem Társadalomföldrajzi Tanszék, Debrecen, pp. 5-23.

SAILER-FLIEGE U. (1996), “Characteristics of post-socialist urban transformation in East Central Europe “, GeoJournal, 49, pp. 7-16.

STRUYK R.J. (1996), "Housing Privatization in the Former Soviet Bloc to 1995 “, in ANDRUSZ G. et al. (eds), Cities after Socialism, Blackwell, Oxford, pp. 192-213.

SZELÉNYI I. (1996), “Cities under socialism - and after “, in ANDRUSZ G. et al. (eds), Cities after Socialism, Blackwell, Oxford, pp. 286-317.

TOSICS I. (2004) "European urban development : Sustainability and the role of housing “, Journal of Housing and the Built Environment, 19, pp. 67-90.

STATISTICS :

ECOSTAT (2010), Ingatlan barométer 2009. IV. negyedév.

HCSO (2010a), “Lakossági lakáshitelezés, 2009. II. félév”, Statisztikai Tükör, 4, 48.

HCSO (2010b), “Lakáspiaci árak, lakásárindex, 2007-2009”, Statisztikai Tükör, 4, 66.

HCSO (2011a), “Lakáspiaci árak, lakásárindex, 2011. II. negyedév”, Statisztikai Tükör, 5, 78.

HCSO (2011b), “A hitellel rendelkezö háztartások szociális jellemzöi”, Statisztikai Tükör, 5, 77.

\section{NOTES}

1. Source: NORRIS F. (2011) "Hungary Blames the Banks", The New York Times, published: September 29, http://www.nytimes.com/2011/09/30/business/global/hungary-blames-thebanks-in-its-mortgage-crisis.html?_r=1\&pagewanted=all

2. Source: RUHAAK A. (2011) Country update Hungary, Rabobank Nederland, http:// www.rabobank.com/content/images/Hungaryupdate-201109_tcm43-105888.pdf.

3. Source : BADKAR M. (2011), Former Eastern Bloc Getting Rocked By Surging Swiss Franc, published : August 3, http://articles.businessinsider.com/2011-08-03/markets/30010208_1_swiss-francswiss-national-bank-mortgage-loans

4. $10^{12}=$ one billion

5. $10^{9}=$ one thousand million ; 1 EUR = app. 310 HUF

6. Source : BALAZS E., SIMON Z. (2011), Hungary to Fix Exchange Rate on Mortgages, End Eviction Ban, Bloomberg Businessweek, published: May 30. http://www.businessweek.com/news/2011-05-30/ hungary-to-fix-exchange-rate-on-mortgages-end-eviction-ban.html

7. Source: RUHAAK A. (2011), Country update Hungary, Rabobank Nederland, http:// www.rabobank.com/content/images/Hungaryupdate-201109_tcm43-105888.pdf 
8. Source: NORRIS F. (2011), "Hungary Blames the Banks", The New York Times, published: September 29, http://www.nytimes.com/2011/09/30/business/global/hungary-blames-thebanks-in-its-mortgage-crisis.html?_r=1\&pagewanted=all

9. Source: RUHAAK A. (2011), Country update Hungary, Rabobank Nederland, http:// www.rabobank.com/content/images/Hungaryupdate-201202_tcm43-105888.pdf

10. Source : BALAZS E., SIMON Z. (2011), Hungary to Fix Exchange Rate on Mortgages, End Eviction Ban , Bloomberg Businessweek, published: May 30. http://www.businessweek.com/news/2011-05-30/ hungary-to-fix-exchange-rate-on-mortgages-end-eviction-ban.html

11. Source: "Banks should pay for forex mortgage crisis - Prime Minister", The Budapest Times, Published: November 7, 2011. http://www.budapesttimes.hu/index.php? option=com_content\&task=view\&id=20878\&Itemid=221

\section{ABSTRACTS}

Housing in Hungary has undergone significant changes since the years of political and economic transition. During the socialist decades the housing sector was controlled by the state, market forces were marginal or non-existent. Thus, one of the biggest changes in housing was the establishment of a western-type residential market after the regime change. The latest worldwide economic crisis has had a dramatic impact on the Hungarian housing market. The turnover of the Hungarian residential market has declined enormously in the past few years. Those families who financed their housing by foreign currency mortgages are facing the hardest situation. The Hungarian forint has significantly weakened against other currencies having resulted in a dramatic increase in foreign currency mortgage payments. First, the paper briefly reviews the literature on housing theories, then it outlines the most important milestones in the development of the Hungarian residential market. The next part of the paper introduces the most problematic issues and areas concerning housing in Hungary, and finally analyzes the effects and consequences of the present economic crisis.

En Hongrie, le logement est confronté à d'importantes mutations depuis les années de transition politique et économique. Durant les décennies du socialisme, ce secteur se trouvait sous le contrôle de l'État et les forces du marché étaient marginales, voire inexistantes. En conséquence, l'un des changements majeurs dans le secteur fut l'établissement d'un marché résidentiel de type occidental à la suite du changement de régime. La dernière crise économique mondiale a eu un impact crucial sur le marché du logement hongrois, dont le chiffre d'affaires a considérablement chuté ces dernières années. Les familles qui finançaient leur logement à l'aide de prêts hypothécaires étrangers se retrouvent dans la situation la plus difficile. La très nette dévaluation du forint par rapport aux autres monnaies a entraîné une hausse significative des remboursements de crédits en monnaie étrangère. Dans un premier temps, l'article analyse la littérature sur les théories du marché du logement et met en évidence les étapes majeures du développement du marché résidentiel hongrois. La seconde partie présente les questions ainsi que les zones les plus problématiques de ce marché avant d'analyser les conséquences de la crise économique actuelle. 
INDEX

Keywords: residential market, housing, migration, global economic crisis, Hungary

Mots-clés: marché résidentiel, logement, migrations, crise économique mondiale, Hongrie

\section{AUTHORS}

\section{MIHÁLY TÖMÖRI}

Geographer, PhD, Department of Social Geography and Regional Development Planning, University of Debrecen, Hungary, Egyetem tér 1, 4032 Debrecen, tmisi2@freemail.hu

\section{ISTVÁN SÜLI-ZAKAR}

University Professor, Dsc., Department of Social Geography and Regional Development Planning, University of Debrecen, Hungary, Egyetem tér 1, 4032 Debrecen, sulizi@tigris.unideb.hu 